\title{
Occupational cadmium exposure in jig solderers
}

\author{
N J SMITH, ${ }^{1}$ M D TOPPING, ${ }^{1}$ J D STEWART, ${ }^{2}$ J G FLETCHER ${ }^{3}$ \\ From the Occupational Medicine and Hygiene Laboratory, ${ }^{1}$ Health and Safety Executive, London NW2 $6 L N$, \\ Employment Medical Advisory Service, ${ }^{2}$ Health and Safety Executive, Birmingham, and Department of \\ Medical Physics, ${ }^{3}$ University of Birmingham, Birmingham, UK
}

\begin{abstract}
The cadmium body burden, blood and urine cadmium concentrations, and renal function were studied in a group of $53 \mathrm{cadmium}$ solderers. The results showed raised blood and urine cadmium concentrations and raised cadmium body burden in all workers (31) with more than five years exposure, with 27 having urine cadmium concentrations in excess of the proposed biological threshold of $10 \mathrm{nmol} / \mathrm{mmol}$ creatinine. Renal tubular dysfunction was found in 17 of the subjects with more than five years exposure and in one this was associated with glomerular dysfunction. These data indicate that cadmium body burden and frequency of tubular dysfunction in end users of cadmium may be as high as those found in smelters or production workers. Subjects with tubular dysfunction did not show greatly increased urine cadmium concentrations compared with those without dysfunction, supporting a previous suggestion that tubular dysfunction occurs before the wash out of cadmium from the kidney. At the time of our study, cadmium exposure stopped as cadmium free soldering rods were introduced. Repeat urine samples from 19 subjects, one to two years after exposure ended indicated that there was no further increase in the level of excretion of low molecular weight proteins, perhaps indicating that the tubular proteinuria does not increase or more severe renal dysfunction develop without continuous exposure.
\end{abstract}

Renal dysfunction associated with chronic cadmium exposure has been recognised since $1948^{1}$ and is characterised by an increased excretion of urinary protein. Changes in tubular and glomerular function occur when the concentration of cadmium in the renal cortex exceeds a "critical" concentration, which may take up to 10-20 years of occupational exposure. Although there have been several well documented studies of cadmium uptake in working populations, ${ }^{23}$ it was not until the development of in vivo neutron activation analysis that the accumulation of cadmium in the kidney could be compared with measures of glomerular and tubular function. ${ }^{45}$ The investigation of the natural history of cadmium accumulation and kidney dysfunction requires access to workers with well documented and stable occupational exposures occurring over many years. With the increased knowledge of the hazards of exposure to cadmium, however, there are fewer populations of workers exposed to cadmium available for study.

During our investigations of the relation between

Accepted 21 April 1986 the uptake of cadmium and renal dysfunction our attention was drawn to a small well defined group of workers, employed in five firms, in a small specialised trade that both manufactures and repairs metal frames (known as jigs). Jigs are used to suspend components for electroplating, mainly in association with the motor component and jewellery trades. These workers had been exposed to fume from cadmium soldering over many years and in each firm the soldering was performed in small workrooms without exhaust ducting or local ventilation. In addition, in some premises there were areas with little or no natural ventilation. There had been no air monitoring at the firms, except for one limited investigation, which indicated air concentrations of cadmium in excess of the control limit-that is $>50 \mu \mathrm{g} / \mathrm{m}^{3}$.

In this report we describe this specialised group of workers, the concentrations of cadmium in liver, kidney, blood, and urine, and how these relate to duration of exposure and renal function, as assessed by measuring urinary $\beta_{2}$-microglobulin, retinol binding protein, and albumin concentrations. The firms changed to cadmium free rods at the time of our survey, giving us the opportunity to initiate a longitudinal study. 


\begin{tabular}{|c|c|c|c|c|c|c|c|}
\hline \multirow[b]{2}{*}{$\begin{array}{l}\text { Employment group } \\
\text { (years) }\end{array}$} & \multirow[b]{2}{*}{ No of subjects } & \multirow[b]{2}{*}{$\begin{array}{l}\text { Mean age } \\
\text { (years) }\end{array}$} & \multirow[b]{2}{*}{ No of smokers } & \multicolumn{3}{|c|}{ Frequency of soldering } & \multirow[b]{2}{*}{$\begin{array}{l}\text { No of subjects for in } \\
\text { vivo measurement }\end{array}$} \\
\hline & & & & Frequent $^{*}$ & $\begin{array}{l}\text { Occasionalt } \\
\text { No of sub }\end{array}$ & $\begin{array}{l}\text { Never or not } \\
\text { recently } \\
\text { cts }\end{array}$ & \\
\hline $\begin{array}{c}0-5 \\
6-10 \\
11-15 \\
16-20 \\
>20\end{array}$ & $\begin{array}{r}21 \\
7 \\
8 \\
10 \\
7\end{array}$ & $\begin{array}{l}28 \\
42 \\
38 \\
41 \\
49\end{array}$ & $\begin{array}{l}9 \\
5 \\
5 \\
7 \\
2\end{array}$ & $\begin{array}{l}3 \\
3 \\
5 \\
5 \\
3\end{array}$ & $\begin{array}{l}2 \\
2 \\
3 \\
2 \\
1\end{array}$ & $\begin{array}{c}16 \\
2 \\
0 \\
3 \ddagger \\
3 \ddagger\end{array}$ & $\begin{array}{l}4 \\
3 \\
5 \\
9 \\
4\end{array}$ \\
\hline
\end{tabular}

*On average more than one day a week.

tOn average less than one day a week, more than one day a month.

† Managers who were regularly engaged in soldering earlier in their careers.

\section{Materials and methods}

\section{STUDY POPULATION}

The study population consisted of the employees of five firms. Each firm was visited and occupational and smoking histories obtained from 53 subjects, over $90 \%$ of the total workforce. Blood and urine samples were obtained from 51 of these and a blood sample only from the two remaining subjects. Subjects exposed for more than five years were encouraged to attend the department of medical physics at the University of Birmingham for in vivo measurement of liver and kidney cadmium concentrations; 21 of the 32 subjects in this category agreed. In addition four subjects with less than five years exposure volunteered for these measurements. A summary of the population data, with the workers divided into five groups depending on the duration of employment in the industry, is given in the table. The amount of soldering performed varied considerably between different individuals, but as all employees were exposed to cadmium fume from the factory atmosphere the data were analysed on the basis that all subjects had been exposed. The six subjects with more than 15 years employment who were in the "never or not recently soldered" group (table) were managers; each had been regularly engaged in soldering earlier in their careers.

\section{BLOOD AND URINE SAMPLES}

Blood samples were stored at $4^{\circ} \mathrm{C}$ until analysis. The urine samples were divided into three aliquots; one was stored at $4^{\circ} \mathrm{C}$ for cadmium analysis, one at $-70^{\circ} \mathrm{C}$ for retinol binding protein measurement, and the third was diluted 1:5 in $\beta_{2}$ microtest buffer (Pharmacia, Uppsala, Sweden) within 24 hour of collection and then stored at $4^{\circ} \mathrm{C}$ until analysis.

\section{ANALYTICAL METHODS}

Blood and urine cadmium concentrations were determined by flameless atomic absorption spectrophotometry. ${ }^{67}$ Urinary $\beta_{2}$-microglobulin concen- tration was determined using the Phadebas $\beta_{2} \vec{\omega}$ microtest kit (Pharmacia, Uppsala, Sweden) according to the manufacturer's instructions, urinary retinol binding protein by an enzyme linked immunosorbent assay (MD Topping et al, unpublished data), and urinary albumin by nephelometry. Kidney and liver cadmium concentrations were determined within six months of the survey by in vivo neutron activation analysis. $^{89}$ As the rate of change of liver and kidney cadmium concentrations is so slow, this time difference is not important.

Blood and urine samples from healthy occupationally unexposed subjects have upper 95 percentile values for blood and urine cadmium of 45 $\mathrm{nmol} / \mathrm{l}$ and $2 \mathrm{nmol} / \mathrm{mmol}$ creatinine respectively ang urinary $\beta_{2}$-microglobulin, retinol binding proteip and albumin of $25 \mu \mathrm{g} / \mathrm{mmol}$ creatinine, $20 \mu \mathrm{g} / \mathrm{mmg}$. creatinine, and $3 \mathrm{mg} / \mathrm{mmol}$ creatinine respective (unpublished laboratory data). In vivo determination of liver and kidney cadmium in occupationally unexposed subjects give 95 percentile values of 7.3 ppm and $7.8 \mathrm{mg}$ respectively.

\section{Results}

BLOOD AND URINE CADMIUM CONCENTRATIONS Results of blood and urine cadmium measurements showed that all workers (32) with more than five years exposure and 11 of the 21 with less than five years exposure had raised concentrations of both blood and urine cadmium, and 30 had urine cadmium concentrations in excess of $10 \mathrm{nmol} / \mathrm{mmol}$ creatinine, a proposed biological threshold value ${ }^{10}$ (figs $1(a)$ and $(b)$ ). Comparison of the mean blood and urine cadmium concentrations for the five exposure groups showed that both increased with exposure up to 15 years and then reached a plateau.

\section{LIVER AND KIDNEY CONCENTRATIONS}

In vivo neutron activation analysis for the measurement of liver and kidney cadmium concentration was performed on 25 subjects: 22 had raised liver and 

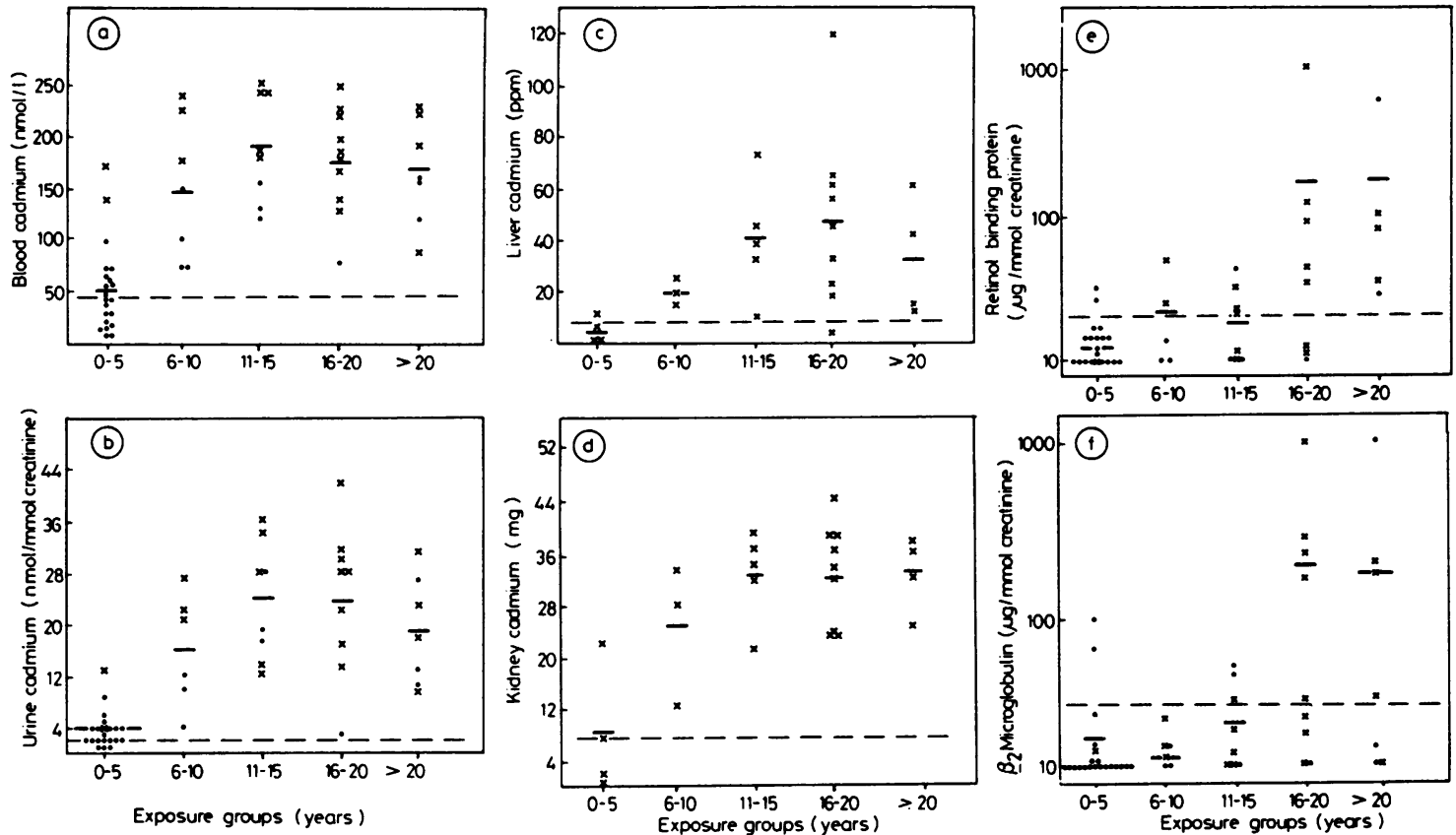

Results for all subjects; x those who underwent in vivo neutron activation analysis for liver and kidney cadmium concentrations, remainder of subjects. (a) blood cadmium (nmol/l), (b) urinary cadmium nmol/mmol creatinine, (c) liver cadmium (ppm), (d) kidney cadmium ( $\mathrm{mg}),(e)$ urinary retinol binding protein ug/mmol creatinine, $(f)$ urinary $\beta_{2}$-microglobulin ug/mmol creatinine. - Group mean value for subjects in that group. -- $95 \%$ cut off value for healthy occupationally unexposed subjects.

kidney cadmium concentrations and urine cadmium concentrations greater than $10 \mathrm{nmol} / \mathrm{mmol}$ creatinine. Of the three remaining subjects, two did not have detectable concentrations of liver and kidney cadmium and one had slightly raised concentrations; they all had low urinary cadmium concentrations. Examination of the group means showed that, like blood and urine cadmium, kidney cadmium increased up to 15 years exposure then reached a plateau whereas liver cadmium increased up to 20 years exposure (figs $1(c)$ and $(d)$ ). The lower level in the 20 or more years group may be due to the change to managerial status of two of the four workers earlier in their careers.

\section{RENAL FUNCTION}

Tubular function was assessed by the measurement of urinary $\beta_{\mathbf{2}}$-microglobulin and retinol binding protein. Concentrations of one or both of these proteins in excess of the upper normal 95 percentile values were seen in 20 of the 51 subjects; however, in eight of these the values were less than twice these upper limit values, indicating that these subjects had mild tubular proteinuria. Comparison of the mean values for each exposure period showed that both proteins remained within normal limits up to 15 years exposure, then increased considerably (figs $1(e)$ and $(f)$ ). Urinary albumin measurements were used to assess gomerular function, values less than the upper 95 percentile were seen in 48 of the 51 subjects; of the remaining three, in only one was the raised value associated with cadmium exposure, one had only been employed for three years, and one had normal values on two subsequent occasions.

CHANGES IN BLOOD AND URINE CADMIUM AND RENAL TUBULAR FUNCTION AFTER CESSATION OF EXPOSURE

Cadmium free soldering rods were substituted for the cadmium solder rods around the time of our survey, consequently occupational exposure to cadmium ended. During the next two years further blood and urine samples were obtained from 19 of the subjects, one to two years after the preceding measurements. For these subjects the mean blood cadmium concentration fell significantly from 220 to $180 \mathrm{nmol} / \mathrm{l}$ (paired $t$ test, $\mathrm{p}<0.05$ ), urinary cadmium concentration fell from 30 to $24 \mathrm{nmol} / \mathrm{mmol}$ creatinine, but 
this was not significant (paired $t$ test $\mathrm{p}>0 \cdot 1$ ), and the mean $\beta_{2}$-microglobulin remained unchanged at $209 \mathrm{ug} / \mathrm{mmol}$ creatinine.

\section{Discussion}

In this study we have documented the relation between blood and urine cadmium concentrations, organ content of cadmium, and the occurrence of low molecular weight proteinuria in a group of workers not studied previously and who had uncontrolled cadmium fume exposure for up to 25 years resulting in considerable accumulation of cadmium in liver and kidneys. This was reflected in increased concentrations of cadmium in blood and urine. Lauwerys and his colleagues ${ }^{10}$ have suggested, after several studies of cadmium workers, that if the urine cadmium concentration was consistently below 10 $\mathrm{nmol} / \mathrm{mmol}$ creatinine, workers would be unlikely to develop renal dysfunction. In this study 27 of the 31 workers with more than five years exposure had urine cadmium concentration considerably in excess of this limit. Roels et al calculated from a study of over 300 workers that if the kidney cortex cadmium concentration did not exceed $216 \mathrm{ppm}$ ( $21 \mathrm{mg}$ for the whole kidney) then $90 \%$ of workers would not develop renal dysfunction ${ }^{11} ; 22$ of the 25 subjects who underwent in vivo neutron activation analysis had kidney cadmium concentrations in excess of this value. It is not surprising, therefore, that 17 of the 31 subjects with more than five years exposure had some evidence of renal tubular dysfunction. Although the values for urinary $\beta_{2}$-microglobulin and retinol binding protein were raised, however, they were not as high as those found in our previous study of cadmium smelters ${ }^{5}$ and, with the exception of one subject, the dysfunction was confined to tubular proteinuria.

It is important to determine whether the removal of cadmium from the working environment of these jig makers prevents progression to more severe renal dysfunction. Our early evidence from the repeat measurements made on these workers does not show increasing excretion of $\beta_{2}$-microglobulin with time, perhaps indicating that this mild tubular proteinuria will not progress to more severe dysfunction now further accumulation of cadmium is unlikely.

In this group of workers urinary cadmium concentrations do not show an increase in parallel with the onset of small molecular weight proteinuria. This supports the earlier suggestion made by Chettle $e t$ al that the onset of low molecular weight proteinuria occurs at a lower kidney cadmium concentration than that at which the kidney fails to retain stored cadmium and that there is a further pronounced increase in urinary cadmium concentration. ${ }^{12}$
Previous studies concerning neutron activation analysis, renal function, and blood and urine cadmium concentrations have all involved cadmium production workers and smelters ${ }^{45}$ but not end users. This study has shown that, without adequate hygiene control, soldering can result in cadmium body burdens comparable with those found in smelters. One interesting observation was the liver and kidney burdens in a group of managers who had not been actively engaged in soldering for several years. This emphasises the need to monitor all personnel in small working premises, as several subjects not currently engaged in soldering may have high cadmium body burdens and in some cases changes in renal function.

Requests for reprints to: $\mathrm{Mr} \mathbf{N} \mathrm{J}$ Smith, Health and Safety Executive, 403 Edgware Road, London NW2 $6 \mathrm{LN}$.

\section{References}

1 Friberg L. Proteinuria kidney injury among workmen exposed to cadmium and metal dust. $J$ Ind Hyg Toxicol 1948;30:32-40.

2 Bernard A, Buchet JP, Roels H, Masson P, Lauwerys R. Renal excretion of proteins and enzymes in workers exposed to cadmium. Eur J Clin Invest 1979;9:11-22.

3 Kjellstrom T, Evrin PE, Rahnster B. Dose-response analysis of cadmium induced tubular proteinuria. Environ Res 197\% 13:303-17.

4 Roels HA, Lauwerys RR, Buchet JP, et al. In vivo measurement of liver and kidney cadmium in workers exposed to this metal: its significance with respect to cadmium in blood and urine. Environ Res 1981;26:217-40.

5 Gompertz D, Chettle DR, Fletcher JG, et al. Renal dysfunction in cadmium smelters: relation to in vivo liver and kidney cadmium concentrations. Lancet 1983;i:1185-7.

6 Delves HT, Woodward J. Determination of low levels of cadmium in blood by electrothermal atomisation and atomic absorption spectrometry. Journal of Atomic Spectroscopy 1981;2:65-7.

7 McAughey JJ, Smith NJ. The direct determination of cadmium in urine by electrothermal atomic absorption spectrometry with the L'vov platform. Anal Chim Acta 1984;156:129-37.

8 McLellan JS, Thomas BJ, Fremlin JH, Harvey TC. Cadmium its in-vivo detection in man. Phys Med Biol 1975;20:88-95.

9 Al-Haddad IK, Chettle DR, Fremlin JH, Harvey TC. Gammaray analysis of renal cadmium by pulsed thermal neutron capture. Journal of Radioanalytical Chemistry 1979;53:203-12.

10 Lauwerys R, Roels H, Regniers M, Buchet JP, Bernard A, Gorel D A. Significance of cadmium concentration in blood and in urine in workers exposed to cadmium. Environ Res 1979;20:375-91.

11 Roels H, Lauwerys R, Dardenne AN. The critical level of cadmium in human renal cortex: a reevaluation. Toxicol Lett 1983;15:357-60.

12 Chettle DR, Coward S, Faddy MJ, et al. Cadmium renal effect levels estimated from analysis of liver and kidney concentrations. In: Wilson D, Volpe RA, eds. Cadmium 83 London: Cadmium Association, 1984:172-4. 